\title{
Factors Affecting Quality of Education after the Introduction of Subsidized Secondary Education Policy in Rongai Sub -County, Kenya
}

\author{
Cynthia B. Awour ${ }^{1}$, Mark I. O. Okere ${ }^{1 *}$, Dolphine Odero-Wanga ${ }^{2}$ \\ ${ }^{I}$ Department of Curriculum, Instruction \& Educational Management, Egerton University, Kenya \\ ${ }^{2}$ Department of Applied Community Development Studies, Egerton University, Kenya
}

*Corresponding Author: Mark I. O. Okere, Department of Curriculum, Instruction \& Educational Management, Egerton University, Kenya

\begin{abstract}
The study investigated factors that affect quality of education after the introduction of Subsidized Secondary Education (SSE) policy in Rongai Sub-County, Kenya. With the introduction of SSE, schools have registered over-enrolment, which means that instructional materials and teaching personnel available in schools could be constrained. One of the objectives of education in Kenya is equipping learners with knowledge, skills, values and attitudes. To be able to achieve this objective, the schools must have adequate learning resources. The adequacy of learning resources was obtained from principals and teachers. The study used Convergent Parallel Mixed Methods research design. The population comprised principals of the 39 schools that participated and 78 teachers (2 randomly selected from each of the 39 public secondary schools), giving a population of 117. Data were collected using questionnaires and interview schedules. Quantitative data were analyzed using descriptive statistics, and thematic approach was used to analyze qualitative data. It has been established that factors that affect quality of education after the introduction of SSE can be categorized as inadequacy of personne, and instructional materials, administration, and politics. The findings will inform policymakers of factors affecting quality of education after the introduction of SSE.
\end{abstract}

Keywords: Learning Resources, Subsidized Secondary Education Policy, Quality of Education

\section{INTRODUCTION}

Education contributes to national development by equipping people with the skills needed for planning for development, providing managerial skills and promoting positive community image for national and societal unity (World Bank, 2012). United Nations declared education as a human right by saying that everyone has the right to education. It also noted that education shall be free at least in the primary and fundamental stages for example, primary education shall be compulsory while Technical and Professional education shall be generally available to all on the basis of merit (United Nations educational and scientific organizations (UNESCO, 2007). In Japan, the government policies provide for free education up to secondary school level. Those of school going age have no option other than attend school to acquire education that is fully funded by the government (Nyaga, 2005). In the United States of America the Federal government supports Public education. The situation in Kenya is not different from that of Japan and America as the government and the communities participate in the provision of the Education (Nyaga, 2005).

Kenya has been trying to achieve the goal of universal education since independence in 1963, with mixed successes. Various approaches which were seen as likely to augment resources and define strategies for education financing more closely adapted to social and economic realities have been suggested and attempted. The most notable (Elimu Yetu Coalition, 2003) was the cost sharing framework, by which the government was to meet salaries of teachers and education administration costs while parents provided tuition fees and textbooks; communities on the other hand were to be responsible for putting up physical facilities and ensuring their maintenance (Government Of Kenya, (GoK, 2008). In 2003, the Government of Kenya, following the 2002 election campaign pledge, introduced the Free Primary Education (FPE) policy in order to universalize access to primary education and increase educational attainment in the country (Republic of Kenya, 2005). This policy was followed later with the Subsidized Secondary Education (SSE) policy in 2008 which equally was 
aimed at accelerating enrollment and quality of secondary education in the country (Odhiambo, 2010). These policies had international backing and credibility, as they were part of the universally agreed Millennium Development Goals (MDGs), and other internationally agreed protocols (Orodho, 2013).

The introduction of Subsidized Secondary Education (SSE) policy was aimed at providing the economically disadvantaged with an opportunity to benefit from government sponsored education provision. This policy tripled the demand for higher education. The Kenya Government announced the release of 2.9 billion for SSE and allocated Ksh. 10,265 to every child to cater for tuition and operational costs annually (Republic of Kenya, 2008).

Quality education can be viewed in terms of the correspondence between the goals, or expectations of society and changes that take place in the learners, the education system and the society as a whole. Expectations of society, according to Mmari (2000), are expressed in terms of educational goals that can broadly be classified into three categories, namely: (i) learning goals, which focus on equipping learners with knowledge, kills, values and attitudes as defined in a given curriculum; (ii) system goals, which relate to measurable inputs and outputs that keep the system working; and (iii) educational goals, which are based on the dominant ideas within society. Since every society has its dominant ideas, it follows that the goals of education between societies will naturally differ; and to that extent the meaning of quality of education will also differ. The discussion about the quality of education in a particular society, therefore, needs to be closely linked to the goals and objectives of education in that society. For example, if the educational goals are defined in terms of learning goals, where the focus is on achievement levels, then quality of education in this respect would be measured in terms of achievement of skills, knowledge, values and attitudes. This also means that the quality of education has to address the issue of relevance, that is, the relevance of educational goals to the needs of a particular society. One of the objectives of education in Kenya is equipping learners with knowledge, kills, values and attitudes as defined in the school curriculum (Republic of Kenya, 2005). And to be able to achieve these goals schools should have adequate learning resources. This study investigated factors that affect quality of education after the introduction of SSE. This was done by asking teachers and principals for their opinions about the adequacy of physical and instructional materials in their schools as well as the adequacy teaching personnel.

\section{PURPOSE OF THE STUdy}

The purpose of the study was to investigate factors that affect quality of education after the introduction of Subsidized Secondary Education in public secondary schools in Rongai Sub County, Kenya.

\section{Methodology}

The study used Convergent Parallel Mixed Methods research design. This involved collecting both qualitative and quantitative data simultaneously. In this approach, a researcher collects both quantitative and qualitative data, analyses them separately, and compares the results to see if the findings confirm or disconfirm each other. In this study, quantitative data were collected using survey questionnaires while qualitative data were collected through the use of interview schedules. Quantitative data were first analyzed using statistical methods, then qualitative data were analyzed using thematic approach, and finally the two types of findings compared. A total of 78 teachers and 39 principals from 39 secondary schools in Rongai Sub County, Kenya participated in the study. Two (2) teachers were randomly selected from each of the 39 schools. Data were collected by use of questionnaires and interview schedules. Questionnaires were administered to the teachers and all principals. Interviews were conducted with five (5) principals randomly selected from the 39 principals. Quantitative data were analysed using descriptive statistics and qualitative data analysed using thematic approach.

\section{Results}

\subsection{Quantitative Analysis}

A structured questionnaire was administered to 39 principals and 78 teachers. The questionnaire items required them to give their opinions about the adequacy of the following learning facilities in their schools: classrooms, laboratories, chemicals, apparatus, library, textbooks, chairs and desks. They 
indicated their pinions using Likert scale with a range from 1 (very inadequate), 2 (inadequate), 3 (not sure), 4 (adequate) and 5 (very adequate). Results of scores from the Principals are given in Table 1.

\subsection{Principals' Responses}

The Principals' questionnaire had items mainly on physical facilities. The results presented here are on facilities that enhance learning. These are classroom, laboratory and library.

Table1. Adequacy of classrooms

\begin{tabular}{|l|l|l|l|}
\hline & \multicolumn{1}{|c|}{ Frequency } & \multicolumn{1}{c|}{ Percent } & Cumulative Percent \\
\hline Very Inadequate & 2 & 5.1 & 5.1 \\
\hline Inadequate & 1 & 2.6 & 7.7 \\
\hline Adequate & 27 & 69.2 & 76.9 \\
\hline Very Adequate & 9 & 23.1 & 100.0 \\
\hline Total Total & 39 & 100.0 & \\
\hline \multicolumn{1}{|c|}{$\mathbf{3 9}$} & & \\
\hline
\end{tabular}

It can be noted from Table 1 that $2(5.1 \%)$ of the Principals said that the classrooms in their schools are very inadequate and $1(2.6 \%)$ said the classrooms are inadequate. What this implies is that, in those schools, not all of the students are in classrooms all the time. Some of them could be learning under trees. This situation definitely affects quality of education because there cannot be meaningful learning when children learn under tress without a blackboard to be used by teachers for illustrations.

Table2. Adequacy of library space

\begin{tabular}{|c|l|l|l|l|}
\hline \multicolumn{2}{|c|}{ Frequency } & & Cumulative Percent \\
\hline \multirow{3}{*}{ Valid } & Very Inadequate & 3 & 7.7 & 7.7 \\
\cline { 2 - 5 } & Inadequate & 25 & 66.7 & 74.4 \\
\cline { 2 - 5 } & Adequate & 2 & 5.1 & 79.5 \\
\cline { 2 - 5 } & Very Adequate & 8 & 20.5 & 100.0 \\
\cline { 2 - 5 } & Total & 39 & 100.0 & \\
\hline \multicolumn{2}{|c|}{ Total } & $\mathbf{3 9}$ & & \\
\hline
\end{tabular}

The information in Table 2 shows that $25(64.1 \%)$ of the Principals said that their schools do not have adequate library space which students can use for private study. This implies that students in those schools do not have the opportunity to do extra reading or search to supplement what they have been taught by their teacher. This inadequacy of reading space affects quality of education because students in those schools will not develop reading culture that enables an individual to search and become a creative thinker.

Table3. Adequacy of laboratory

\begin{tabular}{|l|l|l|l|l|}
\hline \multicolumn{2}{|c|}{ Frequency } & \multicolumn{1}{|c|}{ Percent } & Cumulative Percent \\
\hline \multirow{4}{*}{ Valid } & Very Inadequate & 1 & 2.6 & 2.6 \\
\cline { 2 - 5 } & Inadequate & 25 & 64.1 & 66.7 \\
\cline { 2 - 5 } & Not Sure & 1 & 2.6 & 69.2 \\
\cline { 2 - 5 } & Adequate & 5 & 12.8 & 82.1 \\
\cline { 2 - 5 } & Very Adequate & 7 & 17.9 & 100.0 \\
\cline { 2 - 5 } & Total & 39 & 100.0 & \\
\hline Total & $\mathbf{3 9}$ & & \\
\hline
\end{tabular}

Results in Table 3 show that $25(64.1 \%)$ of the Principals said that they do not have adequate laboratory space. This implies that students in those schools are not acquiring science process skills needed by scientists and technologists. Lack of such skills will hinder the achievement of the 2030 Sustainable Development Goals (SDGs). Thus, the scientific knowledge is not being acquired meaningfully by the learners in those schools. This lack of acquisition of science process skills has a negative impact on the quality of education.

\subsection{Teachers' Responses}

Items in the Teachers' Questionnaire asked questions about the availability of the following instructional materials: textbooks, chemicals and apparatus and computers. Results from the analysis of teachers' responses are given in Tables 4,5 and 6 . 
Factors Affecting Quality of Education after the Introduction of Subsidized Secondary Education Policy in Rongai Sub -County, Kenya

Table4. Adequacy of Textbooks

\begin{tabular}{|l|l|l|l|l|l|}
\hline \multicolumn{2}{|c|}{} & Frequency & Percent & Valid Percent & Cumulative Percent \\
\hline \multirow{3}{*}{ Valid } & Very Inadequate & 36 & 46.2 & 46.2 & 46.2 \\
\cline { 2 - 6 } & Inadequate & 34 & 43.6 & 43.6 & 89.7 \\
\cline { 2 - 6 } & Not Sure & 3 & 3.8 & 3.8 & 93.6 \\
\cline { 2 - 6 } & Adequate & 4 & 5.1 & 5.1 & 98.7 \\
\cline { 2 - 6 } & Very Adequate & 1 & 1.3 & 1.3 & 100.0 \\
\cline { 2 - 6 } & Total & $\mathbf{7 8}$ & $\mathbf{1 0 0 . 0}$ & $\mathbf{1 0 0 . 0}$ & \\
\hline
\end{tabular}

It is clear from Table 4 that, there an acute shortage of textbooks in the secondary schools studied. A high number $36(46.2 \%)$ said that textbooks are very inadequate, and $34(43.6 \%)$ said textbooks are inadequate. The implication of the above results is that students in those schools share the few textbooks available when in class, but some of them will not be able to do assignments when they are at home and this affects quality of learning.

Table5. Adequacy of laboratory chemicals and apparatus

\begin{tabular}{|l|l|l|l|l|}
\hline \multirow{2}{*}{ Valid } & Frequency & Percent & Cumulative Percent \\
\cline { 2 - 5 } & Very Inadequate & 13 & 16.7 & 16.7 \\
\cline { 2 - 5 } & Inadequate & 61 & 78.2 & 94.9 \\
\cline { 2 - 5 } & Adequate & 3 & 3.8 & 98.7 \\
\cline { 2 - 5 } & Very Adequate & 1 & 1.3 & 100.0 \\
\cline { 2 - 5 } & Total & $\mathbf{7 8}$ & $\mathbf{1 0 0 . 0}$ & \\
\hline
\end{tabular}

The majority of teachers $61(78.2 \%)$ said that chemicals and apparatus are inadequate. This implies that, individual class experiments cannot take place in their schools. When chemicals and apparatus are inadequate, teachers perform demonstrations. The disadvantage of demonstrations as compared to class experiments is that, the former does not allow learners to have hands-on experiences. Thus, students in those schools leave without acquiring the scientific attitudes, skills and practices.

Table6. Adequacy of Computers

\begin{tabular}{|l|l|l|l|l|}
\hline \multicolumn{2}{|c|}{ Valid } & Frequency & \multicolumn{1}{c|}{ Percent } & Cumulative Percent \\
\cline { 2 - 5 } & Very Inadequate & 22 & 28.2 & 28.2 \\
\cline { 2 - 5 } & Inadequate & 53 & 67.9 & 96.2 \\
\cline { 2 - 5 } & Adequate & 2 & 2.6 & 98.7 \\
\cline { 2 - 5 } & Very Adequate & 1 & 1.3 & 100.0 \\
\cline { 2 - 5 } & Total & $\mathbf{7 8}$ & $\mathbf{1 0 0 . 0}$ & \\
\hline
\end{tabular}

The teachers who said computers were very inadequate and inadequate were 22 and 53 respectively, giving a total of $75(98.7 \%)$. This result indicates that, the majority of schools in the Sub County do not have computers, and therefore the students from those schools will not contribute to the achievement of 2030 SDGs which require applications of ICT.

\subsection{Thematic Analysis of the Interviews with Principals}

Five (5) principals were interviewed on the factors that affect quality of education after the introduction of SSE. The principals were randomly selected from the 39 who answered the questionnaire.

The following question was asked" What are the factors that affect the quality of SSE in your school?"

The analyses of the transcriptions of the interviews with the Principals on the factors affecting quality of education were grouped into subthemes as shown in Figure 1.

\begin{tabular}{|l|l|l|l|l|l|l|l|l|}
\hline & $\begin{array}{l}\text { Teacher } \\
\text { shortage }\end{array}$ & $\begin{array}{l}\text { Inadequate } \\
\text { facilities } \\
\text { ignorance }\end{array}$ & $\begin{array}{l}\text { Community } \\
\text { : pupil } \\
\text { ratio }\end{array}$ & $\begin{array}{l}\text { Class } \\
\text { size }\end{array}$ & $\begin{array}{l}\text { BOG/ } \\
\text { Teacher } \\
\text { relationship }\end{array}$ & $\begin{array}{l}\text { Late } \\
\text { disburse } \\
\text { ment of } \\
\text { funds }\end{array}$ & politics \\
\hline $\begin{array}{l}\text { Princi } \\
\text { pal A }\end{array}$ & $\begin{array}{l}\text { A sharp rise } \\
\text { enrolment has } \\
\text { put strain on } \\
\text { teachers }\end{array}$ & $\begin{array}{l}\text { There is of } \\
\text { facilities to } \\
\text { serve the } \\
\text { needs of } \\
\text { teachers and } \\
\text { students }\end{array}$ & $\begin{array}{l}\text { There is } \\
\text { ignorance } \\
\text { of the } \\
\text { community } \\
\text { about the } \\
\text { value of } \\
\text { education }\end{array}$ & & & & & \\
\hline
\end{tabular}




\begin{tabular}{|c|c|c|c|c|c|c|c|}
\hline $\begin{array}{l}\text { Princi } \\
\text { pal B }\end{array}$ & & & & $\begin{array}{l}\text { Today } \\
\text { Teacher } \\
\text { : Pupil } \\
\text { ration is } \\
\text { very } \\
\text { high }\end{array}$ & $\begin{array}{l}\text { Quality } \\
\text { of educa } \\
\text {-tion } \\
\text { depends } \\
\text { on class } \\
\text { size }\end{array}$ & $\begin{array}{l}\text { BOG } \\
\text { members } \\
\text { have } \\
\text { inadequate } \\
\text { education }\end{array}$ & \\
\hline $\begin{array}{l}\text { Princi } \\
\text { pal C }\end{array}$ & $\begin{array}{l}\text { To improve } \\
\text { quality of } \\
\text { education it is } \\
\text { important to } \\
\text { have a } \\
\text { teaching force } \\
\text { that is } \\
\text { qualified and } \\
\text { motivated }\end{array}$ & $\begin{array}{l}\text { The } \\
\text { introduction } \\
\text { of SSE has } \\
\text { overstretche } \\
\text { d available } \\
\text { resources }\end{array}$ & & & & $\begin{array}{l}\text { Bad } \\
\text { relationship } \\
\text { between } \\
\text { BOG and } \\
\text { Principals } \\
\text { can affect } \\
\text { implementa } \\
\text { tion of } \\
\text { projects }\end{array}$ & \\
\hline $\begin{array}{l}\text { Princi } \\
\text { pal D }\end{array}$ & $\begin{array}{l}\text { Lack of } \\
\text { training of } \\
\text { teachers is } \\
\text { having } \\
\text { negative } \\
\text { impact on the } \\
\text { quality of } \\
\text { education } \\
\text { Inadequacy of } \\
\text { teachers has } \\
\text { made it hard } \\
\text { to complete } \\
\text { the syllabus }\end{array}$ & & $\begin{array}{l}\text { A lot of } \\
\text { awareness } \\
\text { needs to be } \\
\text { provided to } \\
\text { parents and } \\
\text { students to } \\
\text { eliminate } \\
\text { the attitude } \\
\text { that day } \\
\text { schools are } \\
\text { of low } \\
\text { quality }\end{array}$ & & & & \\
\hline $\begin{array}{l}\text { Princi } \\
\text { pal D }\end{array}$ & & & & & & & $\begin{array}{l}\text { Political } \\
\text { interference } \\
\text { in learning } \\
\text { institutions } \\
\text { especially } \\
\text { running of } \\
\text { institutions } \\
\text { is killing } \\
\text { the quality } \\
\text { of education } \\
\text { offered. }\end{array}$ \\
\hline
\end{tabular}

Figure1. Theme and subthemes of factors affecting quality of education

The factors affecting students' quality of education after the introduction of SSE given by the 5 school Principals were: teacher shortage, inadequate facilities, community ignorance, teacher: pupil ratio, class size, BOG/Teacher relationship, late disbursement of funds and politics. These are presented in Figure 1 as subthemes of the theme "factors affecting quality of education".

The factors can be categorised as personnel, facilities, administration and politics. The personnel factors are teacher shortage, teacher: pupil ratio and class size. Administration factors are BOG/Teacher relationship and late disbursement of funds. Politics involves appointing school heads who are not qualified just because they support particular leaders from the community where the school is located. There is also the belief that Day schools are of low quality as compared to boarding schools.

\subsection{Comparison between Quantitative and Qualitative Findings}

The research design used in this study was Convergent Parallel Mixed Methods design. The research design requires the comparison of the findings obtained from quantitative and qualitative analyses. The objective of the study was to describe factors that affect quality of education after the introduction of SSE. Results from analysis of Principals' and Teachers' questionnaires showed that the factors that affect quality of education are teacher shortages, inadequacy of physical facilities and instructional materials. Interviews with Principals also confirmed the above findings. Results from the interviews gave additional factors that were not captured in the questionnaires. These are: administration factors such as BOG/Teacher relationship and late disbursement of funds; politics involving appointing school heads who are not qualified just because they support particular leaders from the community. 


\section{DISCUSSION}

Asena, et al. (2016) investigated factors affecting subsidized free day secondary education in Bungoma County, Kenya and found an acute shortage of teachers despite the expansion of secondary schools to three streams per class. The finding is in agreement with that of this study of Rongai SubCounty, the majority of the principals who participated in the study cited shortage of teachers as one of the major factors affecting quality of education. According to Mmari (2000) quality education can be viewed in terms of the correspondence between the goals, or expectations of society and changes that take place in the learners, the education system and the society as a whole. In Kenya, one of the goals of education is equipping learners with knowledge, skills, values and attitudes as defined in a given curriculum (Republic of Kenya, 2003). The results obtained from teachers' responses in the present study indicate an acute of learning materials. This implies that the above goal of education is not being realized because it is not possible to impart scientific knowledge, skills and attitudes to students without adequate chemicals and apparatus. According to Qorro (1999), the quality of education is the extent to which objectives are attained. Thus, the lack of instructional materials is affecting the quality of education in Rongai County. Odhiambo (2005) observes that the most important purpose of a school is to provide children with equal and enhanced opportunities for learning, and the most important resource a school has for achieving that purpose is the knowledge, skills and dedication of its teacher. And that increased number of students as a result of $\mathrm{Su}$

bsidized Free Day Secondary Education, teacher students' ratio is likely to be high, leading to increased workload for teachers. A recent study by Gatheru (2008) on challenges related to the implementation of Free Primary Education (FPE) in Narok District, Kenya established that due to the rising number of pupils enrolling in schools, teachers were sometimes overwhelmed and not able to give individualized attention to pupils. Teachers could not mark pupils' assignments and this contributed to a decline in academic performance. This observation has been confirmed in the present study by principals who said that teacher: pupil ratio is very high in their schools.

\section{CONCLUSiON}

- The high enrolment in public secondary schools in Rongai Sub County after the introduction of SSE has overstretched the available facilities, and this has affected quality of education because learners are not able to participate in practical scientific activities.

- Teacher: pupil ratio is high in Rongai Sub County, and this affects quality of education because learners are not able to receive individual attention from the teachers.

- Incompetent school administrators mismanage resources and this affects learning activities.

- Politicians interfere with schools' management.

\section{RECOMMENDATIONS}

- The government should provide schools with adequate learning facilities.

- The number of teachers should be increased.

- School administrators should be retooled to acquire managerial skills.

- Politicians should be advised to stop interfering with school administration.

\section{REFERENCES}

[1] Asena, M. J.,Simiyu, M. A., \& Riechi, A. (2016). Factors Affecting Subsidized Free Day Secondary Education in Enhancing Learners' Retention in Secondary Schools in Kenya. Journal of Education and Practice, Vol.7, No. 20

[2] Gatheru, K. (2008). Challenges Facing Head teachers in the Implementation of Free Primary Education: A Case of Narok District. Kenya: Unpublished Med Project Report, Nairobi: Kenyatta University

[3] Elimu Yetu Coalition (EYC) Kenya's National Education Coalition, the National platform for Civil Society Organizations (CSO)

[4] Mmari, K. (2000). Does Language of Instruction Affect Quality of Education? A Working Paper presented at the monthly 0730 People and Policy Debates jointly organized by HakiElimu and Policy Forum in 2006. 
[5] Nyaga, B. M. (2005). Effects of Delayed Fees Payments on the Teaching and Learning Process in Public Secondary Schools in Mbeere District, Kenya; Unpublished MEd Thesis, Nairobi: Kenyatta University.

[6] Odhiambo, D. (2010). Task force on re-alignment of education to the Constitution 2010 and Vision 20130 and beyond. The Government of Kenya

[7] Odhiambo, G. O. (2005). Teacher appraisal: the experiences of Kenyan secondary school teachers. Journal of Educational Administration, Vol.43 Issue 4, pp. 402-416

[8] Orodho, J. A. (2013). Progress towads attainment of Education for All (EFA) among Nomadic Pastoralist: Do Home - based variables make a Difference in Kenya? Research on Humanities and Social Sciences

[9] Qorro, M. A. S. (1999) 'A Qualitative Study on the Teaching and Learning of Writing in Tanzania Secondary Schools in Relation to Writing Requirements of Tertiary Education', unpublished Ph.D. Thesis, University of Dar es Salaam.

[10] Government of Kenya, (1988).Report of the Presidential Working Party of Education and Manpower Training for the Next Decade and Beyond.(Kamunge).Nairobi: Government Printer.

[11] Government of Kenya, (2005).Kenya Education Sector Support Programme: Delivering Quality Education and Training to all Kenyans. Nairobi:

[12] Republic of Kenya, (2003, October 14). In Search Of Remedy to Secondary School Dropout Pandemic in Kenya. Government Printer

[13] UNESCO, (2007).Education for all by 2015. Will We Make it? Oxford University Press: Oxford.

Citation: Cynthia B. Awour, Mark I. O. Okere, Dolphine Odero-Wanga "Factors Affecting Quality of Education after the Introduction of Subsidized Secondary Education Policy in Rongai Sub -County, Kenya". International Journal of Humanities Social Sciences and Education (IJHSSE), vol 5, no. 3, 2018, pp. 105-111 doi: http://dx.doi.org/10.20431/2349-0381.0503011.

Copyright: (C) 2018 Authors. This is an open-access article distributed under the terms of the Creative Commons Attribution License, which permits unrestricted use, distribution, and reproduction in any medium, provided the original author and source are credited. 